\title{
WASTE IN DESIGN MANAGEMENT OPERATIONS FROM THE VIEWPOINT OF PROJECT NEEDS
}

\author{
Petteri Uusitalo $^{1}$, Joonas Lehtovaara ${ }^{2}$, Olli Seppänen ${ }^{3}$, and Antti Peltokorpi ${ }^{4}$
}

\begin{abstract}
Waste in all project processes is hindering productivity and project's financial goals. Successful design management operations ensure error-free design documentation just in time so that production may start when scheduled with confidence for design quality. However, traditional design management processes aim to remove waste on individual design processes, thus neglecting to view the process as a whole. This research answers the question: How the project participants perceive waste in design management operations, and in which ways the waste could be eliminated? Following a design science research approach, methods applied in this research consist of a single-case study and semi-structured interviews with the project's design-related organization as well as orientation to previous research related to waste in design management process.

Several factors related to waste in design management process are identified, and potential countermeasures are proposed. A conceptual, holistically optimized design management process is presented to remove waste to support project teams' struggle in reaching shared goals. The key aspects are a shared technical design process in combination with decentralized team-based processes, emphasizing designer's resilience and ability to solve uncertain events by themselves. The flow between these two perspectives is acquired by a social collaboration that is initiated through trust.
\end{abstract}

\section{KEYWORDS}

Lean construction, design management, design management operations, process, waste.

\section{INTRODUCTION}

Waste in construction projects emerges in all phases and causes negative outcomes. For example, delayed or erroneous designs and construction documents lead to poor project performance (Rounce, 1998; Tilley, 2005a). El Reifi and Emmitt (2013) highlighted the impact of poor information flow and overly complex designs in design process waste formation. In addition, Tilley (2005b) and Flyvberg (2011), presented the link between

1 Doct. Cand. Department of Civil Engineering, petteri.uusitalo@aalto.fi, orcid.org/0000-0002-7230-0788

2 Doct. Cand. Department of Civil Engineering, joonas.lehtovaara@aalto.fi, orcid.org/0000-0002-4761-3811

3 Assoc. Prof., Department of Civil Engineering, Aalto University, Espoo, Finland, olli.seppanen@aalto.fi, orcid.org/0000-0002-2008-5924

4 Asst. Prof., Department of Civil Engineering, Aalto University, Espoo, Finland, antti.peltokorpi@aalto.fi, orcid.org/0000-0002-7939-6612 
project failure and inefficient design information sharing as well as underestimating the project complexity.

Waste in construction production phase has received a lot of attention due to high cost impact of waste (e.g., Lapinski et al., 2006; Jørgensen and Emmitt, 2008; Sacks et al., 2010). However, research on waste in design management process, which is a crucial part of the whole project, has been lacking the same focus as research on waste in production (e.g., Kagioglou et al., 2000; Smith et al., 2003; Kpamma and Adjei-Kumi, 2011). Hattab \& Hamzeh (2017) argue that the traditional construction project management has ignored the impacts of poor design information flow, which potentially forms a significant source of waste for the following activities in the construction process. Yet, previous research has failed to treat the design management process from a holistic project view. To optimize only the design process, improvement is merely sub-optimized in the context of the whole project. As the design process is intertwined with several crucial decisions within a construction project, sub-optimizing the individual design activity goals are not likely to lead to the best project results. Figure 1 presents a typical sub-optimized situation in a traditionally delivered project.

To aid in reaching goals, the psychological theory of regulatory focus (Higgins, 1998; Florack et al., 2013) distinguishes two mindsets. Promotion focus, where the primary focus is accomplishing goals, the approach is usually positive, creative, and innovative. For promotion-focused people, reaching goals is inspiring. Prevention focus, however, is mainly about preventing losses and focusing on personal safety and security. For prevention-focused people, goals are obligations. While the project people make decisions to solve design issues, the two regulatory focuses influence the psychological mindset and what kind of choices and actions they take. Each of those actions affects the project's social setting. When solving design management problems, Uusitalo et al. (2019b) presented a conceptual framework with two domains, under which those problems were solved, Social domain and Technical domain. The problem-solving factor in Social domain is trust, and the factor in Technical domain is information flow. Previous research has also pointed out, that project participants, especially different design discipline professionals (Akintoye and Main, 2007; Uusitalo et al., 2019b), form a temporary organization and thus social interaction, mostly trust, plays a significant role in the project success (e.g. Smyth, 2005; Wong et al., 2008; Cheung et al., 2013; Akintoye and Main, 2017).

This study approaches the waste in design from the viewpoint of the project participants that are involved in design operations in their daily work. The aim of the study is to explore how project personnel that are participating in design, perceive the waste in design management operations within a project. The study has implications for a better understanding of the possibilities for improving the design management operations flow from the holistic project point of view. The aim is pursued by answering a research question:

RQ: How the project participants perceive waste in design management operations, and in which ways the waste could be eliminated? 


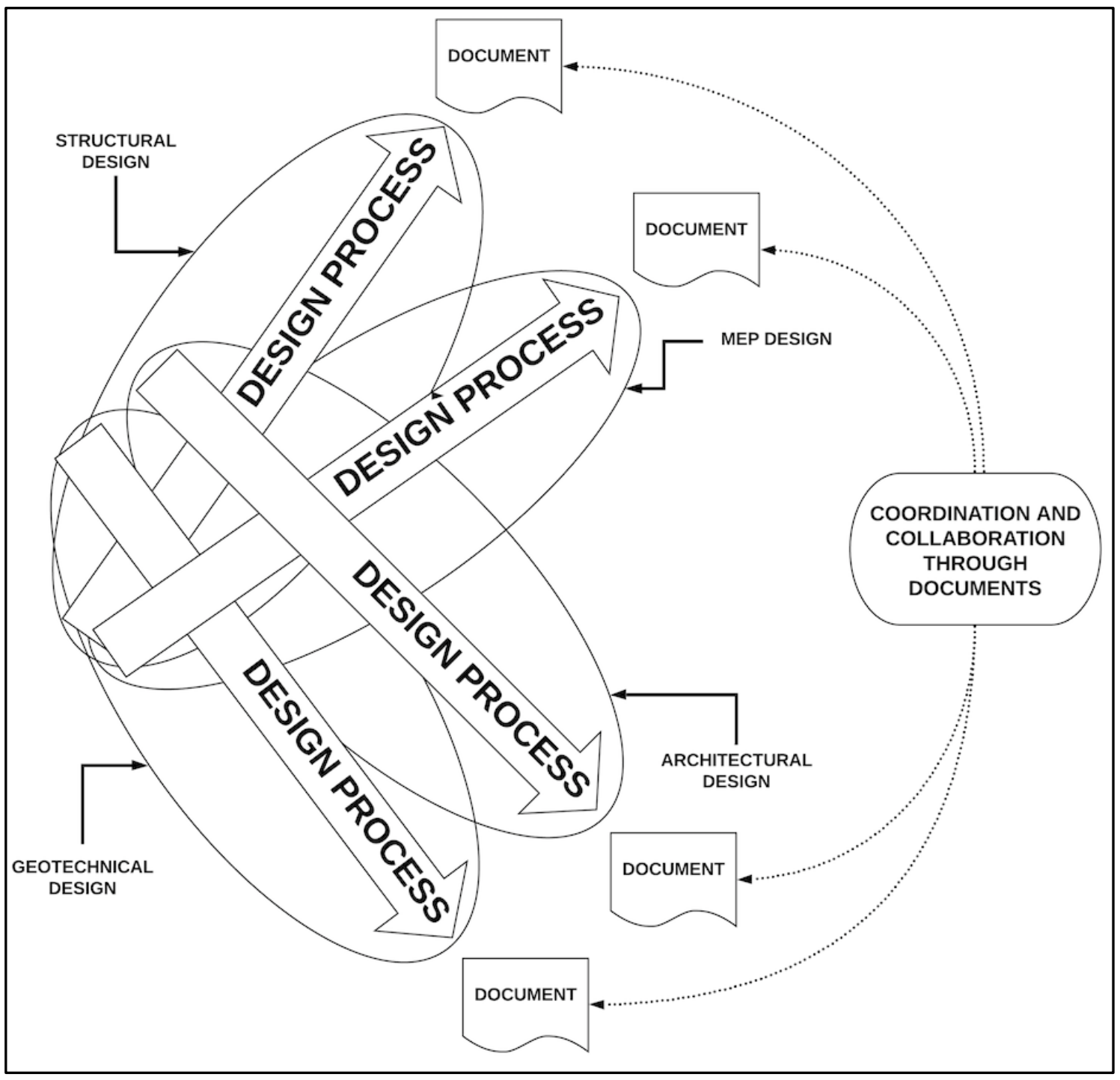

Figure 1: A traditional sub-optimal design process

\section{METHODS}

The nature of the selected methodology is design science research (Hevner et al., 2004), which is found to be practical when aligning the academic side of lean construction with its industry equivalent (Smith, 2015). The study was conducted as a single-case study, consisting of an analysis of the design phase of an 82-apartment residential building project in Finland. At the time of the case study, the project was running in the detailed design phase, partially overlapping with the preliminary design and construction phases. The design management was orchestrated by a developer/GC, also responsible for the architectural design. Throughout the design phases, collaborative 'studio' sessions were conducted to coordinate the design schedules and solutions between the developer/GC and design consultants.

To elucidate the stance of construction professionals on design management issues related to the case project, 11 semi-structured interviews involving 11 professionals were conducted. The interviewed professionals and their organizations are presented in Table 1. The selection of the interviewees was carried out by reviewing a project's 
organizational network in the context of the design process. This was conducted through one structured interview of the project design manager (who also participated in the project as an architect) with an observation of project documentation. Each interview followed a predetermined plan, and the length of the sessions varied from 30 minutes to 65 minutes. All informants were briefed on the purpose of the research and that their interview data was not going to be used outside the study and that all data was going to be completely anonymized. The recorded interviews were stored in a private-access network, and only the research team has the rights to access data. In addition, the interviewees filled a brief orientation survey before the interview sessions, where they were asked questions regarding the communication flow and decision-making processes during the project. Furthermore, the survey answers were reflected upon during the interviews.

The recorded interviews were transcribed verbatim. Transcripts were analyzed and coded with data analysis software ATLAS.ti Version 8.4.4. The analysis of the interviews followed an iterative approach in two phases. To identify the informants' perceptions related to design management process and waste, first, three main themes were categorized. The categories for the main themes were reflected based on the social and technical aspects in the project setting as well as promoting the importance of a team in reaching project goals. In the second analysis phase, thematic codes were formed during iterative analysis and connected to the main themes.

Table 1: Interviewees and their design discipline and organization

\begin{tabular}{ccc}
\hline $\mathbf{N}: \mathbf{0}$ & Interviewee & Organization \\
\hline $1 \& 2$ & Project design manager / architect & Developer/GC \\
& (two sessions, structured and semi-structured) & \\
3 & Project manager & Developer/GC \\
4 & Procurement manager & Developer/GC \\
5 & Site engineer & Developer/GC \\
6 & Structural designer & Structural design \\
& & consultant \\
7 & MEP designer & MEP design consultant \\
8 & Electrical design project manager \& Electrical designer & Electrical design \\
9 & BIM coordinator & Developer/GC \\
10 & Precast concrete element project manager & Concrete element \\
& & provider \\
11 & Precast concrete element designer & Concrete element \\
& & provider \\
\hline
\end{tabular}

Finally, after prescribing the problem, a conceptual model was proposed to be utilized as a countermeasure for the identified problems. The actual implementation phase of the developed model is part of future research, as the present study reports exclusively the problem and solution concept. 


\section{FINDINGS}

The main themes in interview analysis are categorized as 'Technical design process,' 'Social design process,' and 'Team and project processes'. Factors, from the second phase, that are associated with waste are grouped under the three main issues are presented in Table 2. After each factor, there is an illustrative extract from the transcribed interview material. The number inside the brackets indicates the number of mentions related to each factor.

\section{FINDINGS - TECHNICAL DESIGN PROCESS}

Design information flow was observed as a major issue from the viewpoint of project flow. Uncertainty about the design status and level of detail (LOD), had a significant impact on both the design process itself and starting the procurement and production phases. Most of the challenges were either in coordination and inadequate input information or in scheduling the design process without sufficiently agreed details. Many of the interviews also revealed, in some form, a discrepancy between design document revisions and unstructured documenting of those revisions.

On the other hand, project participants perceived that designs were inspected too late, while the requested LOD was higher than needed. This resulted in wasted effort and confusion about the status of the design process. The designers would mostly prefer to finish the design from start to finish in one go, and they would also like to work on the whole building rather than smaller sections. The interviewees had different views on delivering the design in smaller batches tied to production progress. This raises a challenge on how to produce design information in smaller batches to support the production and procurement, and so that the project would find a compromise between removing the waste in an individual design process and reaching the project goal with success.

The use of building information model (BIM) was considered useful in the project; however, the project's BIM-coordinator stated that the BIM-model was not fully utilized in an optimal manner, especially during the production phase of the project. There is motivation to use the BIM-model, but as it was not fully utilized in the design process either, the utilization did not lead to optimally coordinating issues and removing waste.

\section{FINDINGS - SOCIAL DESIGN PROCESS}

Communication and Trust received the most mentions from the interview answers. Trust had a dual nature related to project success. Trust was seen as a root cause in success, as trust lowers the threshold to discuss problems and aids in solving them. Trust also diminishes the need to micromanage. Trust helps in generating swiftness and agility in process because trust raises confidence in the work of others and therefore lowers the need to double-check the received information.

The Studio-sessions (adapted Last Planner System-sessions) in the case study were seen mostly as beneficial practices; however, some mentions emerged that those sessions were rather long and that issues on the agenda could have been dealt with a smaller group. Some equated time spent in Studio-session as time "wasted." Especially in the middle of the project rush, between few hours allocated to any specific project, design coordination in a Studio-session could seem to appear futile if that supersedes time from technical design efforts. 
Table 2: Categories and issues related to design management process waste. Findings from the interviews

\begin{tabular}{|c|c|c|}
\hline Theme & Factors & Illustrative extracts from interviews \\
\hline \multirow{5}{*}{$\begin{array}{l}\text { Technical } \\
\text { design } \\
\text { process }\end{array}$} & $\begin{array}{l}\text { Information flow } \\
\qquad(21)\end{array}$ & $\begin{array}{l}\text { "In [building information] models, the revision marks are often not as clear as in } \\
\text { traditional (2D) drawings." }\end{array}$ \\
\hline & $\begin{array}{l}\text { File naming } \\
\text { convention } \\
\quad(2)\end{array}$ & $\begin{array}{l}\text { “...but sometimes designers save drawings with some odd number-letter } \\
\text { combinations, which have no relation to the content of the drawing. It's } \\
\text { frustrating to open drawings one by one and check what they contain." }\end{array}$ \\
\hline & $\begin{array}{l}\text { Point of inspection } \\
\text { too late } \\
\text { (26) }\end{array}$ & $\begin{array}{c}\text { "We have observed single mistakes, ... mistakes that could have been avoided } \\
\text { with earlier design inspections." }\end{array}$ \\
\hline & $\begin{array}{l}\text { Too detailed design } \\
\text { too early } \\
\text { (5) }\end{array}$ & $\begin{array}{c}\text { "I am not certain if is it about the technology - that the used software is not } \\
\text { adequate, or what is it, but I feel that the designers are forced to do things earlier } \\
\text { than they would want to. They kind of do more than what had been actually } \\
\text { required." }\end{array}$ \\
\hline & $\begin{array}{l}\text { Details without proper } \\
\text { prerequisites } \\
\text { (29) }\end{array}$ & $\begin{array}{c}\text { "There have been occasions where the design schedule has caused a sense of } \\
\text { urgency, and then we design without prerequisites, and then, correct the designs } \\
\text { afterwards." }\end{array}$ \\
\hline \multirow{3}{*}{$\begin{array}{l}\text { Social } \\
\text { design } \\
\text { process }\end{array}$} & $\begin{array}{l}\text { Communication } \\
(24)\end{array}$ & $\begin{array}{l}\text { "For example, on the site we noticed that a sink was located in different location } \\
\text { in MEP-designs than in architectural designs. There was some kind of } \\
\text { communication gap -I did not notice the sink was re-located to another side of the } \\
\text { room. The designs were already sent to the site and the workers already installed } \\
\text { the plumbing in wrong location before we noticed." }\end{array}$ \\
\hline & $\begin{array}{l}\text { Trust } \\
(24)\end{array}$ & $\begin{array}{c}\text { "Trust affects especially on the speed to act. That you trust that the given } \\
\text { information is right. Otherwise, without trust, the design process would be } \\
\text { slower." }\end{array}$ \\
\hline & $\begin{array}{l}\text { Unnecessary meetings } \\
\qquad(2)\end{array}$ & $\begin{array}{c}\text { "Maybe these studio sessions kind of [include waste]. When people start } \\
\text { discussing on some individual design matter, do you really need fifteen people to } \\
\text { listen two persons arguing?" }\end{array}$ \\
\hline \multirow{4}{*}{$\begin{array}{l}\text { Team and } \\
\text { project } \\
\text { processes }\end{array}$} & $\begin{array}{l}\text { Building permit } \\
\text { officials } \\
\text { (8) }\end{array}$ & $\begin{array}{c}\text { There were [problems] with the permit process also. When the designs went } \\
\text { through the permit process, the officials wanted new designs three times and no } \\
\text { solution was satisfactory." }\end{array}$ \\
\hline & $\begin{array}{l}\text { Individual goals vs. project } \\
\text { goals } \\
\text { (12) }\end{array}$ & $\begin{array}{c}\text { "... that's why we want to choose the equipment by ourselves, so that the designs } \\
\text { would contain that kind of products we already have in the storage .... and there } \\
\text { would not be some special equipment for every project..." }\end{array}$ \\
\hline & $\begin{array}{l}\text { Resources } \\
\text { (3) }\end{array}$ & $\begin{array}{c}\text { "I am the third project manager for this project, the first person who started the } \\
\text { project left for a maternity leave, and after her the second responsible person } \\
\text { stayed in the position for a few months, but left for another employee. After that I } \\
\text { was appointed as the project manager, and before I started, my supervisor was } \\
\text { leading the project for a while." }\end{array}$ \\
\hline & $\begin{array}{l}\text { Responsible party } \\
\text { (30) }\end{array}$ & $\begin{array}{c}\text { “... the allocation of responsibilities between project manager and design manager } \\
\text { has not necessarily been that clear. I don't know where the responsibilities change. } \\
\text { Sometimes it has been one person in charge [in the design process], and } \\
\text { sometimes two." }\end{array}$ \\
\hline
\end{tabular}

\section{FINDINGS - TEAM AND PROJECT PROCESSES}

The project participants stated that a major cause of waste in the process was due to the periodically tight design schedule, which was primarily a result of personnel changes (resources) and delayed building permit process. The tight schedule led to large workloads for designers and required extra personal effort from the designers to meet the project goals. Furthermore, the rush was perceived to transform the process towards 'firefighting mode, ' where designers 'do what they can' and 'only prioritize the work that requires immediate action.' However, it was stated that regardless of the rush, the design 
process was perceived to achieve the required project goals, mainly due to the flexibility of the designers.

Designers' overall workflow was primarily determined by the project or design manager by design batches (such as by floors). Within the batches, designers were provided the freedom to plan their own workflow by their own preferences. However, the designers felt that they were not fully able to plan and control their own work due to the constant flow of (sometimes contradictory) requirements from different project parties that changed the prioritization and were often not predictable for the designers. Designers were not able to optimize their own optimal workflow in most of the time, but mainly prioritized works that were most critical from the viewpoint of other parties. The requirements from other projects furthermore increased the reactiveness of the design work. Even though being able to plan their work on a daily level, the designers felt that often requirements from the project manager, design manager, or supervisor were contradictory with the optimal design flow on a weekly or monthly basis.

\section{DISCUSSION}

In summary, these results show that the problems are connected to unstructured behaviour for managing the maturity, timing, and flow of the design information. Collaborative meetings suffered from a lack of pre-planned agenda in regard to who should attend; however, the need for better communication was noted. The designers experienced an absence of control over their own workflow as well as several contradicting, often surprising, pulls from other project parties. The main connecting theme to these problems is that the project has several unaligned goals, and each individual is aiming for different goals as well as weekly changing those goals.

\section{TECHNICAL DESIGN PROCESS}

Broft \& Pryke (2019) pointed out that individual organizations strive to focus on the efficiency of their own subprocesses. Thus, when optimizing a single design process by minimizing waste, for example, waiting, over processing, or unused employee creativity (Mazlum and Pekericli, 2016), the risk of missing the benefit of value-creating iteration (Hansen and Olsson, 2011) increases. Kpamma and Adjei-Kumi (2011) argued that transferring the information in smaller batches would eliminate waste in the design process. Uusitalo et al. (2019a) proposed a lean design management process that is applied to manage the LOD of design information and connect that information to location-based production in smaller batches, thus creating a pull to design information. Also, the proposed process utilizes collaborative methods, such as the Last Planner System (LPS) to determine the correct level and quantity of information and their milestones. This process would create a structured approach to managing the information flow, which would help to solve waste identified related to the maturity and timing of design information flow as well as help the inspection process by delivering information in smaller batches as identified in the study.

\section{SOCIAL DESIGN PROCESS}

Communication might not improve by spending more time communicating. According to findings, trust is clearly a root cause in improving the social aspects of the design process. In the early phases of the project, gained trust and efforts to seek common ground and shared goal, is crucial. Social interaction is stronger in trustful project settings, thus facilitating collaboration with less resources (Uusitalo et al., 2019b). Applying LPS in 
design management promotes social interaction among an inter-organizational design team, thus leading to increased levels of trust. Better trust leads to better communication and collaboration (e.g., Smyth, 2005; Wong et al., 2008; Cheung et al., 2013; Issa et al., 2017) as well as creates a positive spiral in projects social setting (Uusitalo et al., 2019b). Teamwork and rearranging design tasks lower the effort needed to transfer information, thus leading to eliminate waste in the design process (Kpamma and Adjei-Kumi, 2011). Also, strengthening the social surrounding in a project to activate more promotion focus like mindset, (Florack et al., 2013) could help the team to reach common goals more effectively. As a solution to identified problems, related to further improving trust and communication, scheduling consistently recurring LPS-sessions would be an ideal solution.

\section{TEAM AND PROJECT PROCESSES}

According to study findings, the main problems at a project level are poor prioritization and inconsistency in aligning individual goals as well as not knowing who is the responsible party for each topic. However, the findings implicate that it may not be necessary to attempt to align the individual design team's process and project technical design process tightly together for improving the designer's workflow. Instead, if a clearly determined and transparent technical design process for the project is provided, it could be beneficial to enable more loosely coupled systems between the individual teams to provide the designers a better opportunity to optimize their own work proactively, with a longer timeframe than a single day. Loosely coupled and decentralized decision-making has been proposed as a key enabler in managing complex processes (e.g., Howell \& Ballard 1998, Bertelsen \& Koskela 2004). Decentralization has perceived to offer a complementary aspect for Lean Construction principles (Saurin et al. 2013) that offers room to fill the gaps between codified process and management of uncertain events that inevitably occur during the design operations. Instead of attempting to micromanage the designer's workflow by several managers, providing support for the designers to increase their resilience and ability to proactively solve the problems through their preferred decentralized processes could yield a significantly lesser amount of waste in the process.

\section{HOLISTICALLY OPTIMIZED DESIGN PROCESS}

To reflect back to the research question (How the project participants perceive waste in design management operations, and in which ways the waste could be eliminated?), instead of aiming to provide different documents, design operations should be treated from a more holistic viewpoint. The conceptual model for the holistically optimized design process is presented in Figure 2. The figure illustrates how different design disciplines focus on the common shared goal instead of their own individual goals and how the shared process combines different organizations.

We propose that the key aspects for decreasing waste from the project perspective in the design are i) shared technical design process utilizing LOD, which is combined with ii) decentralized team-based processes, emphasizing designer's resilience and ability to solve uncertain events by themselves. The flow between these two perspectives is acquired by iii) social collaboration that is initiated through trust. The contribution to knowledge is that we now have a deeper understanding of the identified actual field problem. Based on the identified problem, the proposed conceptual model combines the efforts of individual design disciplines holistically in a previously untried manner to reach a shared goal optimally at a project level instead of optimizing individual sub-processes. 


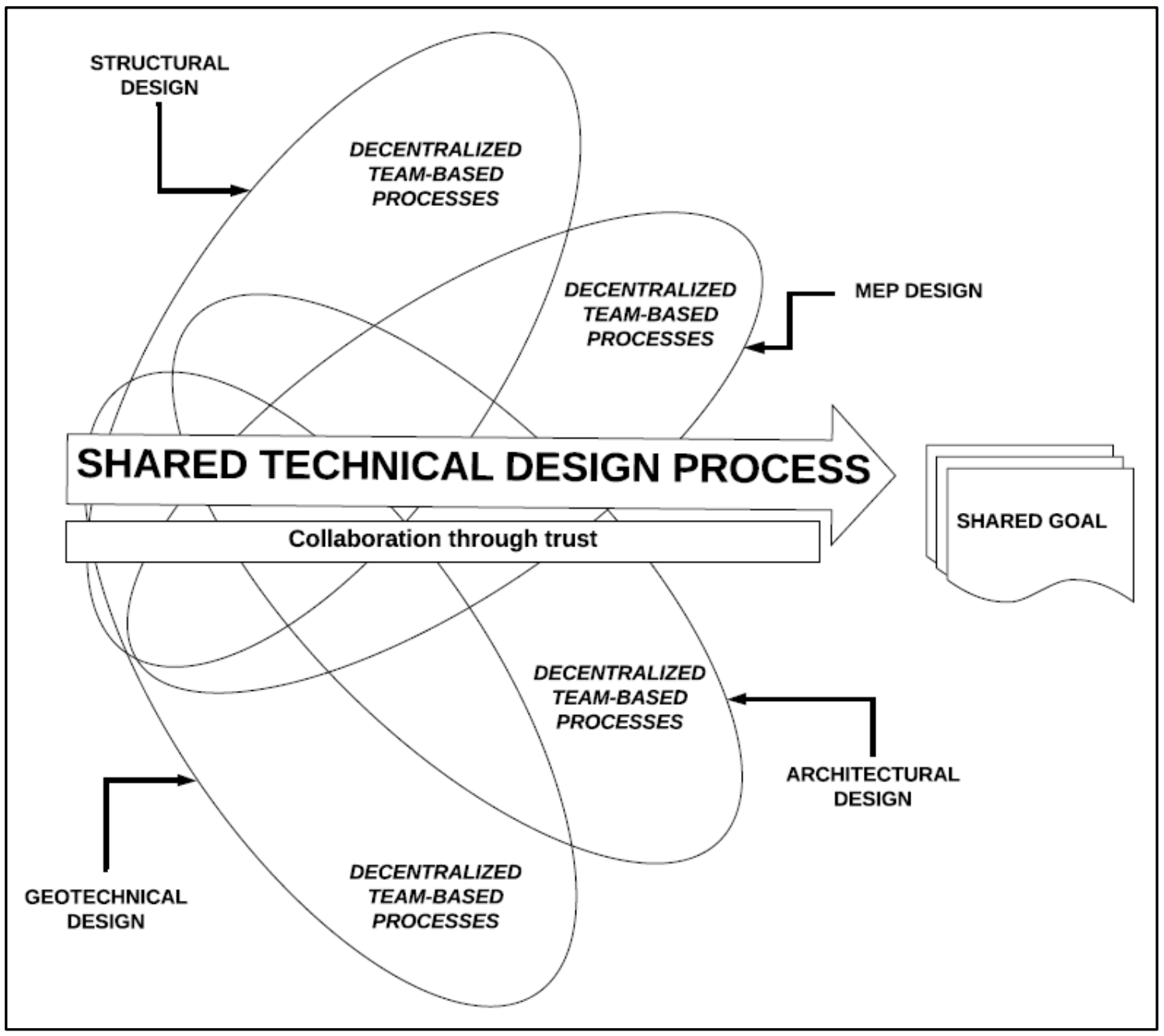

Figure 2: Holistically optimized design process

\section{CONCLUSIONS}

Projects usually have many goals, and project organization may reach those goals through many routes. To reach all the project goals successfully, project participants all have to reach those same goals. In the context of design operations, the design process must support the construction efforts and enable the participants to work as a collaborative team. A holistically optimized design process should cover both social and technical aspects of design operations.

The proposed holistic approach promotes a "project first" mentality, thus preventing the aim of removing all waste from individual design processes but rather optimizing the whole. Structuring the process to support the pull of location-based construction by taking advantage of design information LOD and organizing collaborative team processes in a trustful project environment, is a possible answer for more successful projects. To evaluate the feasibility and to weigh the impacts of the proposed approach, future research effort should include implementing all the elements in a traditional project setting.

\section{ACKNOWLEDGMENTS}

This research was funded by DiCtion (digitalizing construction workflows) project. 


\section{REFERENCES}

Akintoye, A. and Main, J. (2007), "Collaborative relationships in construction: the UK contractors' perception." Engineering, Construction and Architectural Management, Vol. 14 No. 6, pp. 597-617.

Broft, R. D. and Pryke, S. 2019, "Supply Chain Rhythm: Multidisciplinary Teams Through Collaborative Work Structuring" In:, Proceedings of the 27th Annual Conference of the International Group for Lean Construction (IGLC). Dublin, Ireland, 3-5 Jul 2019. pp 1261-1270

Bertelsen, S., and Koskela, L. (2004). "Construction beyond lean: a new understanding of construction management." In Proceedings of the 12th annual conference in the International Group for Lean Construction.

Cheung, S. O., Yiu, T. W., and Lam, M. C. (2013). "Interweaving trust and communication with project performance." Journal of Construction Engineering and Management, 139(8), pp. 941-950.

Chinowsky, P., Diekmann, J., and Galotti, V. (2008). "Social network model of construction." Journal of construction engineering and management, 134(10), 804812.

El Reifi, M.H. and Emmitt, S. (2013), "Perceptions of lean design management." Architectural Engineering and Design Management, Vol. 9 No. 3, pp. 195-208.

Florack, A., Keller, J., and Palcu, J. (2013). Regulatory focus in economic contexts. Journal of Economic Psychology, 38, 127-137.

Flyvbjerg, B. (2011), "Over budget, over time, over and over again: managing major projects." in Morris, P.W.G., Pinto, J.K. and Söderlund, J. (Eds), Oxford Handbook of Project Management, Oxford University Press, Oxford, pp. 321-344.

Hansen, G. K., and Olsson, N. O. (2011). "Layered project-layered process: Lean thinking and flexible solutions." Architectural Engineering and Design Management, $7(2), 70-84$.

Hevner, A. R., March, S. T., Park, J., and Ram, S. (2004). Design science in information systems research. MIS quarterly, 75-105.

Higgins, E. T. (1998). Promotion and prevention: Regulatory focus as a motivational principle. In M. P. Zanna (Ed.). Advances in Experimental Psychology (Vol. 30, pp. 1-46). San Diego, CA: Academic Press.

Howell, G., and Ballard, G. (1998). "Implementing lean construction: understanding and action." Proceedings of the 6th Annual Conference of the International Group for Lean Construction.

Al Hattab, M., and Hamzeh, F. (2017). "A Process-Social Perspective for Understanding Design Information Flow." Lean Construction Journal.

Issa, R. R., Olbina, S., and Zuppa, D. (2018). Model for developing trust on US construction projects. Built Environment Project and Asset Management.

Jørgensen, B., and Emmitt, S. (2008). "Lost in transition: the transfer of lean manufacturing to construction." Engineering, Construction and Architectural Management, 15(4), 383-398.

Lapinski, A. R., Horman, M. J., and Riley, D. R. (2006). "Lean processes for sustainable project delivery." Journal of construction engineering and management, 132(10), 1083-1091.

Kagioglou, M., Cooper, R., Aouad, G., and Sexton, M. (2000). "Rethinking construction: the generic design and construction process protocol." Engineering, construction and architectural management, 7(2), 141-153. 
Kpamma, E. Z., and Adjei-Kumi, T. (2011). "Management of waste in the building design process: The Ghanaian consultants' perspective." Architectural Engineering and Design Management, 7(2), 102-112.

Mazlum, S. K., and Pekericli, M. K. (2016). "Lean Design Management-An Evaluation Of Waste Items For Architectural Design Process." METU Journal of the Faculty of Architecture, 33(1).

Rounce, G. (1998). "Quality, waste and cost considerations in architectural building design management." International Journal of Project Management, 16(2), 123-127.

Sacks, R., Radosavljevic, M., and Barak, R. (2010). "Requirements for building information modeling based lean production management systems for construction." Automation in construction, 19(5), 641-655.

Saurin, T. A., Rooke, J., and Koskela, L. (2013). "A complex systems theory perspective of lean production." International Journal of Production Research, 51(19), 58245838.

Smith, J., Georgiou, J., O'Keeffe, N., and Love, P. (2003, January). “Design management in a design-construct organization." Proc. 19th Annual Association of Researchers in Construction Management Conference (pp. 131-140). Association of Researchers in Construction Management.

Smith, J. P. (2015). "A Case Study on Design Science Research as a Methodology for Developing Tools to Support Lean Construction Efforts." In: Proceedings of the 23rd Annual Conference of the International Group for Lean Construction. Perth, Australia, 29-31 Jul 2015. pp 517-526

Smyth, H. (2005). "Trust in the design team." Architectural engineering and design management, 1(3), pp. 211-223

Tilley, P. (2005a). "Design and Documentation Quality Problems-A Lean Thinking Opportunity." In: Proceedings of the International SCRI Symposium, Salford, UK, pp. 12-13.

Tilley, P.A. (2005b), "Lean design management: a new paradigm for managing the design and documentation process to improve quality?" In: Proceedings of the 13th International Group for Lean Construction Conference, Sydney, pp. 283-295.

Uusitalo, P., Seppänen, O., Lappalainen, E., Peltokorpi, A., and Olivieri, H. (2019a). "Applying Level of Detail in a BIM-Based Project: An Overall Process for Lean Design Management." Buildings, 9(5), 109.

Uusitalo, P., Seppänen, O., Peltokorpi, A. and Olivieri, H. (2019b), "Solving design management problems using lean design management: the role of trust." Engineering, Construction and Architectural Management, Vol. 26, No. 7, pp. 1387-1405.

Wong, W.K., Cheung, S.O., Yiu, T.W. and Pang, H.Y. (2008), "A framework for trust in construction contracting." International Journal of Project Management, Vol. 26, No. 8, pp. 821-829. 